\title{
PERBEDAAN LOKASI DAN WAKTU TANAM TERHADAP PERTUMBUHAN DAN HASIL KEDELAI DI LAHAN SAWAH NUSA TENGGARA BARAT
}

\author{
Sutrisno dan Andy Wijanarko \\ Balai Penelitian Tanaman Aneka Kacang dan Umbi \\ Jl. Raya Kendalpayak Km 08 Kotak Pos 66 Malang 65101 \\ Email: uthisharun@gmail.com
}

\begin{abstract}
Planting time has a big influence on the growth and yield of soybean plants. This study aims to determine the response of the growth and yield of soybean at different planting times. The research was conducted in the villages of Sesela and Kebon Indah, West Lombok Sub-district, West Nusa Tenggara in 2017. Anjasmoro variety soybean were planted in two different locations and five different times between July and August with range around week. Growth variables observed were plant height, number of fertile books, number of filled pods, number of empty pods, number of branches, weight of biomass, number of seeds, and seed weight per plant. Results showed that soybean planted at the beginning period produced higher growth and yields compared to soybean planted at the end of the period. The difference in location affects the growth and yield of plants except for the plant height component and the number of fertile books per plant.
\end{abstract}

Keywords: soybean, planting time, soil fertility, rainfall, temperature

\section{PENDAHULUAN}

Nusa Tenggara Barat (NTB) merupakan provinsi penghasil kedelai terbesar ketiga di Indonesia setelah Provinsi Jawa Timur dan Jawa Tengah. Produksi kedelai di NTB pada tahun 2015 tercatat sebanyak 125.000 ton dengan luas area sekitar 95 ribu ha atau memiliki produktivitas sekitar 1.3 ton per ha. Produktivitas ini sebenarnya relatif masih rendah karena banyak hasil penelitian menyebutkan bahwa produktivitas kedelai varietas unggul baru nasional sudah mencapai 2 - 3,5 ton per ha (Balitkabi, 2016). Rendahnya produktivitas ini kemungkinan disebabkan oleh ketidaktepatan waktu budidaya dan ketidakseragaman waktu tanam.

Budidaya kedelai di Lombok Barat Nusa Tenggara Barat khususnya daerah persawahan umumnya dilakukan ketika mulai masuk musim kemarau atau setelah budidaya padi. Pola tanam dalam kurun waktu satu tahun biasanya berupa padi-padi-kedelai, padi-kedelai-kedelai, atau padi-kedelai-padi tergantung kondisi ketersediaan air pada musim berjalan. Selain itu status kepemilikan lahan atau kepemilikan sewa relatif sempit pada masing-masing petani dan kekompakan petani dalam manajemen waktu tanam masih rendah sehingga periode waktu tanam dalam satu hamparan lahan menjadi 
berbeda-beda dengan rentang yang lebar. Perbedaan waktu tanam yang lebar berpengaruh besar terhadap keberhasilan budidaya kedelai (Bastidas et al. 2008).

Keberhasilan budidaya kedelai sangat dipengaruhi oleh faktor lingkungan terutama ketersediaan air. Tanaman kedelai yang ditanam pada periode awal kemungkinann besar dapat tumbuh dan memberikan hasil normal karena masih dapat memperoleh air relatif cukup sedangkan tanaman periode akhir kemungkinan akan mengalami kekurangan air sehingga pertumbuhan dan hasil kedelai menjadi rendah. Hasil penelitian menyebutkan bahwa tanaman kedelai yang mengalami hambatan pertumbuhan pada tinggi tanaman, jumlah cabang, biomassa tanaman, jumlah polong isi, meningkatkan jumlah polong hampa, dan mengurangi jumlah biji dan ukuran biji sehingga tidak dapat terisi secara maksimal (Hu and Wiatrak, 2012). Kondisi ini akan menyebabkan petani memperoleh hasil panen sedikit.

Fluktuasi suhu harian yang lebar dan peningkatan suhu pada musim kemarau kemungkinan besar juga dapat mempengaruhi pertumbuhan tanaman kedelai. Tanaman kedelai yang pada periode awal mengalami fluktuasi suhu yang ekstrim kemungkinan akan mangalami hambatan pertumbuhan sehinga tanaman kedelai menjadi kerdil dan akhirnya tidak dapat memberikan hasil. Hasil penelitian lain menunjukkan bahwa fluktuasi suhu dapat menurunkan pertumbuhan tinggi tanaman, jumlah polong isi, jumlah biji, ukuran biji dan hasil biji per tanaman (Brevedan dan Egli, 2003; Pedersen dan Lauer, 2004).

Perbedaan lahan dapat juga menjadi faktor pembatas keberhasilan budidaya kedelai. Setiap lahan memiliki karakter kesuburan berbedabeda sehingga lahan subur akan menghasilkan pertumbuhan dan hasil tanaman kedelai lebih tinggi dibandingkan tanaman yang ditanam di lahan kurang subur. Faktor kesuburan dan faktor iklim akan saling berinteraksi untuk menentukan pertumbuhan dan hasil tanaman kedelai (Sundari dan Taufiq, 2012). Oleh karena itu, penelitian ini bertujuan untuk mengetahui dampak perbedaan waktu tanam dan perbedaan lokasi terhadap pertumbuhan dan hasil kedelai.

\section{BAHAN DAN METODE}

Penelitian dilaksanakan di Desa Sesela Dusun Sesela dan Dusun Kebun Indah Kecamatan Gunung Sari Kabupaten Lombok Barat NTB pada Juli - November 2017. Perlakuan terdiri dari lima perbedaan waktu tanam yaitu (1) 19-20 Juli, (2) 29-30 Juli, (3) 7 Agustus, (4) 17 Agustus, dan (5) 24 Agustus 2017 dengan menggunakan varietas kedelai Anjasmoro. Perlakuan diterapkan pada rancangan kelompok teracak lengkap dengan 
tiga ulangan. Kedelai ditanam dengan jarak tanam $40 \times 15 \mathrm{~cm}$ dengan jumlah benih 2-3 butir per lubang tanam. dengan ukuran petak 25 x $25 \mathrm{~m}$.

Persiapan lahan dimulai dengan aplikasi herbisida setelah panen padi. Dua hari setelah aplikasi herbisida kedelai ditanam sesuai ${ }^{2} \mathrm{~d}$.... 1 tanam. Tanam kedelai dilakukan secara manual menggunakan tugal. Penyiangan gulma dilakukan pada umur antara 20 hst menggunakan herbisida untuk gulma yang tumbuh antabaris dan secara manual untuk gulma yang tumbuh dalam baris. Aplikasi pupuk NPK Phonska dilaksanakan pada saat tanaman berumur $10 \mathrm{hst}$ dengan dosis $150 \mathrm{~kg}$ per ha. Selain itu juga diaplikasikan pupuk daun gandasil D dan B serta pupuk cair Atonik pada fase vegetatif dan generatif kedelai. Pengendalian hama dilakukan sekali yaitu menjelang berbunga hanya sebagai antisipasi jika terjadi serangan hama saat pembungaan dan pembentukan polong menggunakan Prevaton.

Pengamatan dilakukan pada saat panen. Komponen pertumbuhan yang diamati pada saat panen adalah tinggi tanaman, jumlah cabang, jumlah buku subur, jumlah polong isi, jumlah polong hampa, jumlah biji per tanaman, bobot 100 biji, dan bobot biji per tanaman.
Semua variabel pengamatan tersebut diamati secara manual.

Data pengamatan komponen pertumbuhan dan hasil kedelai dianalisis menggunakan uji analisis sidik ragam dengan Uji F. Apabila terdapat perbedaan nyata dilanjutkan dengan analisis pemisahan nilai tengah menggunakan uji pembanding BNT pada alpha/ tingkat kesalahan $5 \%$.

\section{HASIL DAN PEMBAHASAN}

Jumlah curah hujan tiap minggu antara tanggal 19 Juli hingga 30 November 2019 di Lombok Barat NTB disajikan pada Gambar 1. Pada gambar tersebut terlihat jelas bahwa curah hujan sedikit terjadi di setengah awal periode tanaman namun terjadi lonjakan jumlah curah hujan di setengah akhir periode. Periode awal curah hujan terjadi pada minggu ketiga dengan jumlah curah hujan hanya sekitar $20 \mathrm{~mm}$ per minggu namun pada periode setengah akhir, jumlah curah hujan mencapai 50 pada minggu ke 12 dan meningkat menjadi 60 dan 180 pada minggu ke 15 dan 19. Kondisi ini berpengaruh besar terhadap pertumbuhan tanaman dan proses panen kedelai karena tanaman kedelai mengalami kekurangan air pada periode awal pertumbuhan dan mengalami kelimpahan curah hujan pada periode generatif akhir atau menjelang panen hingga saat prosesing panen. 


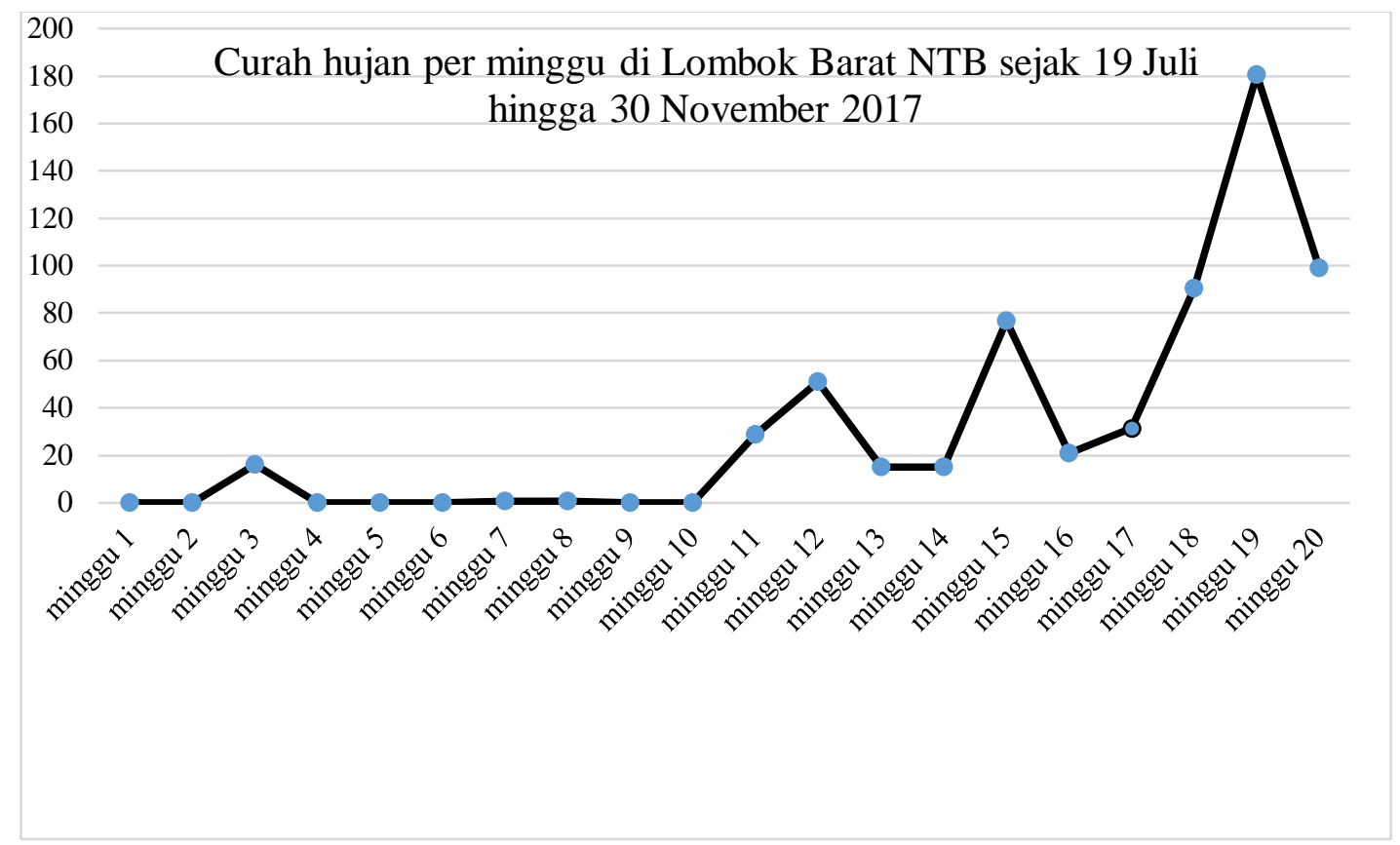

Gambar 1. Jumlah curah hujan per minggu selama periode waktu tanam kedelai di Sesela dan Kebun Indah Gunung Sari Lombok Barat NTB tahun 2017.

Suhu maksimum dan minimum harian selama periode 19 juli hingga 10 oktober 2019 atau hingga minggu ke 13 setelah tanam kedelai pertama menunjukkan variasi suhu relatif sedikit meningkat (Gambar 2). Namun pada minggu ke 5 hingga ke 7, fluktuasi suhu relatif melebar. Rata-rata suhu pagi hari pada minggu ke enam mencapai $18^{\circ} \mathrm{C}$ bahkan pada tanggal 16 Juli pada minggu tersebut mencapai $17^{\circ} \mathrm{C}$. Rendahnya suhu tersebut dapat mempengaruhi pertumbuhan kedelai. Hasil penelitian sebelumnya menyebutkan suhu antara $18-13{ }^{\circ} \mathrm{C}$ dapat menurunkan pertumbuhan kedelai fase awal (Egli dan Wardlaw, 1980). Perbedaan waktu tanam berpengaruh besar terhadap penurunan tinggi tanaman. Kedelai yang ditanam lebih awal (pertengahan hingga akhir juli) menghasilkan keragaan tanaman lebih tinggi daripada tanaman yang ditanam di akhir musim (Agustus). Pada awal musim, tinggi tanaman kedelai dapat mencapai $72,48 \mathrm{~cm}$ sedangkan pada periode akhir tinggi tanaman hanya mampu mencapai 41,98 $\mathrm{cm}$ saja atau mengalami penurunan pertumbuhan sebesar $42 \%$. Penurunan pertumbuhan ini disebabkan oleh pengaruh curah hujan. Tanaman periode awal mampu mencapai pertumbuhan optimal karena pada minggu ketiga setelah tanam tanaman masih memperoleh curah hujan namun pada tanaman periode akhir (yang ditanam sekitar minggu ke 5 dan 6) tanaman tidak memperoleh curah hujan hingga minggu ke 
Fluktuasi suhu minimum dan maksimum per minggu di Lombok Barat NTB sejak 19 Juli hingga 10 Oktober 2017

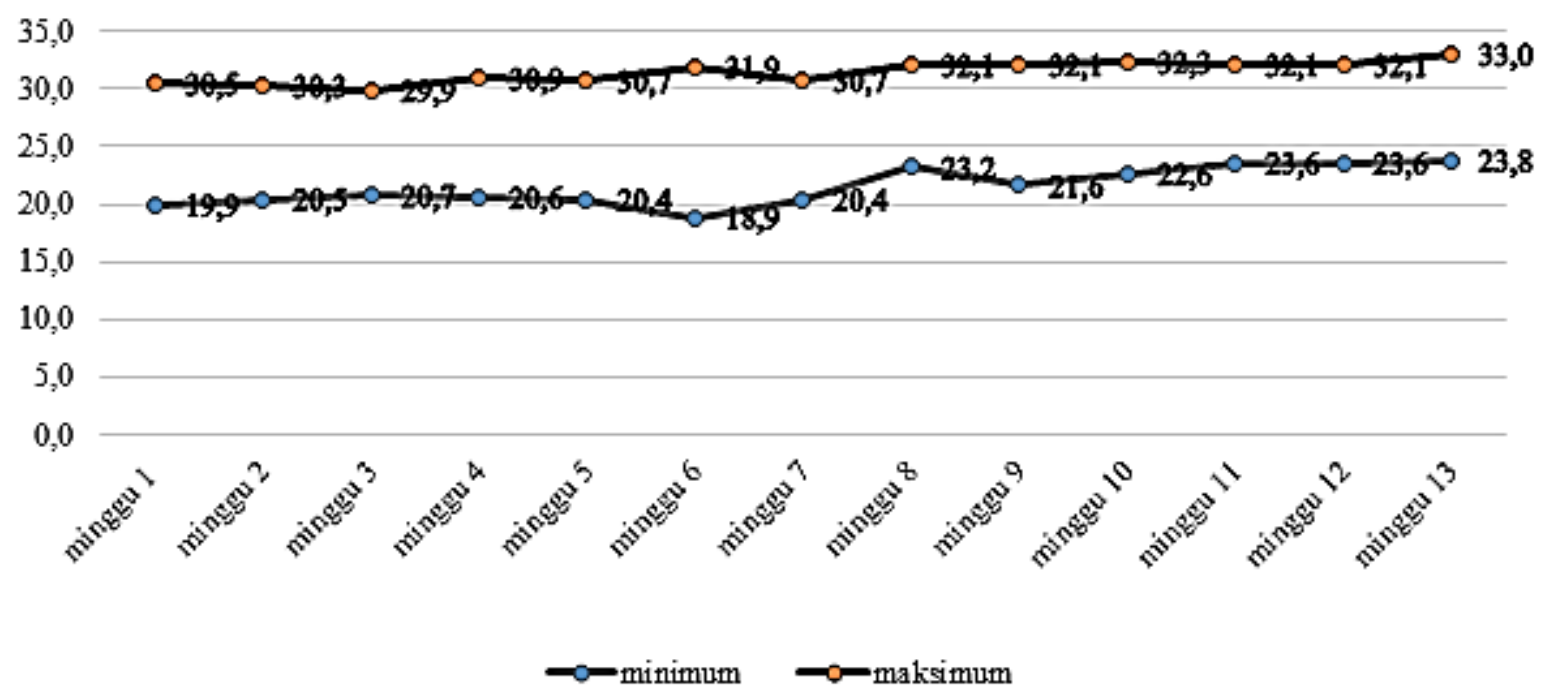

Gambar 2. Fluktuasi suhu minimum dan maksimum per minggu selama periode waktu tanam kedelai di Sesela dan Kebun Indah Gunung Sari Lombok Barat NTB tahun 2017

sepuluh (Gambar 1). Kondisi tanah yang kering dan ditambah dengan kondisi rentang suhu harian yang lebar antara minggu ke 5 -7 (Gambar 2) menyebabkan pertumbuhan tanaman periode akhir menjadi terhambat. Hasil penelitian sebelumnya menyebutkan bahwa suhu rendah menghambat pertumbuhan tanaman kedelai (Rahman, et al. 2006).

Jumlah buku subur semakin berkurang pada tanaman kedelai periode akhir. Pada tanaman awal periode, tanaman kedelai menghasilkan buku subur sebanyak 13 buku sedangkan pada pertengahan dan akhir berturut-turut menghasilkan 10 dan 8 buku atau mengalami pengurangan jumlah buku subur berturut-turut mencapai $23 \%$ dan 38\%. Pengurangan jumlah buku subur ini berhubungan erat dengan penurunan pertumbuhan tinggi tanaman. T anaman yang memiliki keragaan pendek hanya mampu menghasilkan sedikit jumlah buku subur. Cekaman kekeringan dan suhu menjadi faktor pembatas utama dalam pertumbuhan vegetatif ini. Hasil penelitian Settimi dan Board (1988) menyebutkan bahwa perbedaan waktu tanam, penurunan suhu, dan penyinaran dapat menghambat pertumbuhan dan pertambahan jumlah cabang kedelai. Jumlah polong isi bervariasi antarlokasi dan antarwaktu tanam. Pada Dusun Sesela, jumlah polong isi paling 
Tabel 1. Tinggi tanaman dan jumlah buku subur kedelai Anjasmoro pada lima perbedaan waktu tanam di Dusun Kebun Indah dan Sesela Gunung Sari Lombok Barat NTB tahun 2017.

\begin{tabular}{ccc}
\hline $\begin{array}{c}\text { Perbedaan } \\
\text { Waktu tanam }\end{array}$ & $\begin{array}{c}\text { Tinggi } \\
\text { tanaman }\end{array}$ & $\begin{array}{c}\text { Jumlah buku subur/ } \\
\text { tanaman }\end{array}$ \\
19-20 Juli 2017 & $72.48 \mathrm{a}$ & $12.69 \mathrm{a}$ \\
29-30 Juli 2017 & $63.48 \mathrm{~b}$ & $12.19 \mathrm{a}$ \\
7 Agustus 2017 & $48.38 \mathrm{c}$ & $10.08 \mathrm{~b}$ \\
17 Agustus 2017 & $48.10 \mathrm{c}$ & $9.45 \mathrm{bc}$ \\
24 Agustus 2017 & $41.98 \mathrm{~d}$ & $8.75 \mathrm{c}$ \\
\hline Rata & 54.88 & 10.63 \\
cv & 5.77 & 7.78 \\
\hline Perbedaan Lokasi & & $10.43 \mathrm{a}$ \\
Kebon indah & $57.54 \mathrm{a}$ & $10.84 \mathrm{a}$ \\
\hline Rata & $52.22 \mathrm{~b}$ & 10.63 \\
cv & 54.88 & 7.78 \\
\hline
\end{tabular}

Ket: Nilai sekolom yang diikuti huruf yang sama dinyatakan tidak berbeda nyata berdasarkan uji BNT

banyak diperoleh pada kedelai awal periode tanam dan kemudian berkurang secara signifikan pada tanaman periode akhir. Namun pada Dusun Kebon Indah, Jumlah polong isi paling banyak diperoleh tanaman periode pertengahan. Pengaruh perbedaan lokasi terhadap waktu tanam juga hanya tampak pada jumlah polong isi tanaman periode awal. Pada kedelai periode pertengahan dan akhir, jumlah polong isi pada kedua lokasi relatif sama. Hasil penelitian ini menunjukkan bahwa cekaman lingkungan berupa kekeringan dan temperatur tampaknya lebih dominan mempengaruhi pertambahan jumlah polong isi dibandingkan perbedaan faktor kesuburan pada kedua lokasi.
Kondisi penurunan jumlah polong isi juga didukung dengan penampilan jumlah polong hampa. Tanaman kedelai yang menghasilkan sedikit jumlah polong isi menghasilkan jumlah polong hampa lebih sedikit. Pada Dusun Sesela periode tanam pertama misalnya, jumlah polong isi diperoleh 65 dan jumlah polong hampa sebanyak 3 polong. Sebaliknya pada periode akhir tanam, jumlah polong isi Dusun Sesela sebanyak 35 polong sedangkan polong hampanya sebanyak 9 polong. Fakta ini menunjukkan bahwa semakin tercekam kekeringan tanaman tidak mampu menghasilkan biji sesuai dengan jumlah polong yang sudah terbentuk. 
Tabel 2. Jumlah polong isi dan polong hampa biji kedelai Anjasmoro pada lima perbedaan waktu tanam di Dusun Kebun Indah dan Sesela Gunung Sari Lombok Barat NTB tahun 2017.

\begin{tabular}{ccccc}
\hline \multirow{2}{*}{$\begin{array}{c}\text { Jerbedaan } \\
\text { Waktu tanam }\end{array}$} & $\begin{array}{c}\text { Jumlah polong isi/ tanaman } \\
\text { Kebon Indah }\end{array}$ & $\begin{array}{c}\text { Jusun } \\
\text { Sesela }\end{array}$ & $\begin{array}{c}\text { Dusun } \\
\text { Kebon Indah }\end{array}$ & $\begin{array}{c}\text { Dusun } \\
\text { Sesela }\end{array}$ \\
\cline { 2 - 5 } 19-20 Juli 2017 & $39.30 \mathrm{~b}$ & $64.95 \mathrm{a}$ & $2.05 \mathrm{bc}$ & $3.04 \mathrm{~b}$ \\
& $(\mathrm{~b})$ & $(\mathrm{a})$ & $(\mathrm{b})$ & $(\mathrm{a})$ \\
$29-30$ Juli 2017 & $42.98 \mathrm{~b}$ & $51.90 \mathrm{~b}$ & $1.45 \mathrm{c}$ & $2.55 \mathrm{~b}$ \\
& $(\mathrm{a})$ & $(\mathrm{a})$ & $(\mathrm{b})$ & $(\mathrm{a})$ \\
7 Agustus 2017 & $54.65 \mathrm{a}$ & $45.20 \mathrm{~b}$ & $4.50 \mathrm{a}$ & $7.70 \mathrm{a}$ \\
& $(\mathrm{a})$ & $(\mathrm{a})$ & $(\mathrm{a})$ & $(\mathrm{a})$ \\
17 Agustus 2017 & $42.10 \mathrm{~b}$ & $49.81 \mathrm{c}$ & $2.75 \mathrm{bc}$ & $9.05 \mathrm{a}$ \\
& $(\mathrm{a})$ & $(\mathrm{a})$ & $(\mathrm{a})$ & $(\mathrm{a})$ \\
24 Agustus 2017 & $33.45 \mathrm{~b}$ & $35.40 \mathrm{c}$ & $3.70 \mathrm{ab}$ & $8.65 \mathrm{a}$ \\
& $(\mathrm{a})$ & $(\mathrm{a})$ & $(\mathrm{a})$ & $(\mathrm{a})$ \\
\hline Rata-rata & 45.97 & 45.97 & 4.54 & 4.54 \\
Cv & 14.63 & 14.63 & 25.24 & 25.24 \\
\hline
\end{tabular}

Ket: Nilai sekolom yang diikuti huruf yang sama dan nilai sebaris pada setiap variabel pengamatan yang diikuti huruf yang sama dinyatakan tidak berbeda nyata berdasarkan uji BNT pada taraf nyata $5 \%$.

Perbedaan waktu tanam dan lokasi berpengaruh besar terhadap pembentukan jumlah cabang per tanaman. Tanaman periode awal menghasilkan jumlah cabang lebih banyak dibandingkan tanaman periode akhir. Jumlah cabang pada tanaman Dusun Sesela juga lebih banyak dibandingkan pada Dusun Kebon Indah terutama pada tanaman awal periode namun pada tanaman akhir periode relatif sama pada kedua lokasi. Fakta ini menunjukkan bahwa cekaman kekeringan akibat perbedaan waktu tanam sangat menekan pertumbuhan jumlah cabang.

Hasil penelitian Settimi dan Board (1988) menyebutkan bahwa perbedaan waktu tanam, penurunan suhu, dan penyinaran dapat menghambat pertumbuhan dan pertambahan jumlah cabang kedelai.

Bobot biomasa tanaman kedelai periode awal pada Dusun Kebon Indah dan Sesela berturut-turut mencapai 13 dan 19 g per tanaman. Bobot biomasa semakin menurun pada tanaman periode berikutnya dan pada tanaman periode akhir hanya memperoleh bobot biomasa $10 \mathrm{~g}$ per tanaman atau mengalami penurunan sebesar $47 \%$. Perbedaan bobot biomasa paling besar hanya terjadi pada tanaman periode awal sedangkan pada tanaman periode akhir relatif sama. Penurunan bobot biomasa ini disebabkan oleh adanya cekaman kekeringan. Hasil penelitian sebelumnya juga menyatakan bahwa cekaman kekeringan berpengaruh nyata terhadap penurunan biomasa 
Tabel 3. Jumlah cabang dan bobot biomasa kedelai Anjasmoro pada lima perbedaan waktu tanam di Dusun Kebun Indah dan Sesela Gunung Sari Lombok Barat NTB tahun 2017.

\begin{tabular}{ccccc}
\hline $\begin{array}{c}\text { Perbedaan } \\
\text { Waktu tanam }\end{array}$ & $\begin{array}{c}\text { Jumlah cabang/ tanaman } \\
\text { Dusun } \\
\text { Kebon Indah }\end{array}$ & $\begin{array}{c}\text { Dusun } \\
\text { Sesela }\end{array}$ & $\begin{array}{c}\text { Bobot biomass/ tanaman (g) } \\
\text { Dusun } \\
\text { Kebon Indah }\end{array}$ & $\begin{array}{c}\text { Dusun } \\
\text { Sesela }\end{array}$ \\
\hline $19-20 \mathrm{Juli}$ & $2.15 \mathrm{a}$ & $3.44 \mathrm{a}$ & $12.48 \mathrm{ab}$ & $19.72 \mathrm{a}$ \\
2017 & $(\mathrm{~b})$ & $(\mathrm{a})$ & $(\mathrm{b})$ & $(\mathrm{a})$ \\
$29-30 \mathrm{Juli}$ & $2.28 \mathrm{a}$ & $2.30 \mathrm{bc}$ & $13.78 \mathrm{a}$ & $17.80 \mathrm{ab}$ \\
2017 & $(\mathrm{a})$ & $(\mathrm{a})$ & $(\mathrm{b})$ & $(\mathrm{a})$ \\
7 Agustus & $2.25 \mathrm{a}$ & $1.85 \mathrm{~cd}$ & $15.00 \mathrm{a}$ & $13.97 \mathrm{c}$ \\
2017 & $(\mathrm{a})$ & $(\mathrm{a})$ & $(\mathrm{a})$ & $(\mathrm{a})$ \\
17 Agustus & $2.05 \mathrm{a}$ & $2.45 \mathrm{~b}$ & $11.99 \mathrm{ab}$ & $14.68 \mathrm{~b}$ \\
2017 & $(\mathrm{a})$ & $(\mathrm{a})$ & $(\mathrm{a})$ & $(\mathrm{a})$ \\
24 Agustus & $1.40 \mathrm{~b}$ & $1.50 \mathrm{~d}$ & $9.73 \mathrm{~b}$ & $9.79 \mathrm{~d}$ \\
2017 & $(\mathrm{a})$ & $(\mathrm{a})$ & $(\mathrm{a})$ & $(\mathrm{a})$ \\
\hline Rata-rata & 18.32 & 18.32 & 13.89 & 13.89 \\
Cv & 2.17 & 2.17 & 16.09 & 16.09 \\
\hline
\end{tabular}

Ket: Nilai sekolom yang diikuti huruf yang sama dan nilai sebaris pada setiap variabel pengamatan yang diikuti huruf yang sama dinyatakan tidak berbeda nyata berdasarkan uji BNT pada taraf nyata $5 \%$.

tanaman (Hapsoh dkk 2004; Bahrun dkk 2012).

Jumlah biji per tanaman berkurang signifikan pada kedelai tanaman periode akhir. Pengurangan tersebut berturut-turut mencapai 15\% dan 53\% pada Dusun Kebon Indah dan Dusun Sesela. Penurunan jumlah biji pertanaman ini dipengaruhi oleh ketersediaan air. Tanaman yang ditanam pada periode akhir, pada masa vegetatifnya sudah mengalami kekurangan air sehingga tanaman kedelai kesulitan untuk membentuk biji. Hasil penelitian lain menyebutkan bahwa kekurangan air pada fase vegetatif muda sangat menekan laju pertumbuhan dan pembentukan biji kedelai (Nugraha, et al. 2014). Bobot biji pertanaman mengalami pengurangan signifikan pada kedelai yang ditanam pada periode akhir. Pada Dusun Sesela, tanaman periode awal menghasilkan bobot biji sebanyak $23 \mathrm{~g}$ per tanaman sedangkan pada kedelai periode akhir tanam hanya menghasilkan $12 \mathrm{~g}$ periode tanam atau mengalami penurunan hasil sebesar $48 \%$. Pada Dusun Kebon Indah tanaman kedelai mengalami penurunan hasil sebesar 15\% (dari $13 \mathrm{~g}$ menjadi $10 \mathrm{~g}$ ). 
Tabel 4. Jumlah biji dan bobot biji kedelai Anjasmoro pada lima perbedaan waktu tanam di Dusun Kebun Indah dan Sesela Gunung Sari Lombok Barat NTB tahun 2017.

\begin{tabular}{ccccc}
\hline $\begin{array}{c}\text { Perbedaan } \\
\text { Waktu tanam }\end{array}$ & $\begin{array}{c}\text { Jumlah biji/ tanaman } \\
\text { Dusun } \\
\text { Kebon Indah }\end{array}$ & $\begin{array}{c}\text { Dusun } \\
\text { Sesela }\end{array}$ & $\begin{array}{c}\text { Bobot biji per tanaman } \\
\text { Dusun } \\
\text { Kebon Indah }\end{array}$ & $\begin{array}{c}\text { Dusun } \\
\text { Sesela }\end{array}$ \\
\hline 19-20 Juli 2017 & $80.96 \mathrm{ab}$ & $144.35 \mathrm{a}$ & $13.36 \mathrm{abc}$ & $23.15 \mathrm{a}$ \\
& $(\mathrm{b})$ & $(\mathrm{a})$ & $(\mathrm{b})$ & $(\mathrm{a})$ \\
29-30 Juli 2017 & $88.91 \mathrm{a}$ & $109.65 \mathrm{~b}$ & $14.78 \mathrm{ab}$ & $19.68 \mathrm{~b}$ \\
& $(\mathrm{~b})$ & $(\mathrm{a})$ & $(\mathrm{b})$ & $(\mathrm{a})$ \\
7 Agustus 2017 & $86.05 \mathrm{ab}$ & $88.25 \mathrm{c}$ & $16.05 \mathrm{a}$ & $17.87 \mathrm{~b}$ \\
& $(\mathrm{a})$ & $(\mathrm{a})$ & $(\mathrm{a})$ & $(\mathrm{a})$ \\
17 Agustus & $87.20 \mathrm{ab}$ & $93.35 \mathrm{bc}$ & $13.10 \mathrm{bc}$ & $18.20 \mathrm{~b}$ \\
2017 & $(\mathrm{a})$ & $(\mathrm{a})$ & $(\mathrm{b})$ & $(\mathrm{a})$ \\
24 Agustus & $68.75 \mathrm{~b}$ & $67.00 \mathrm{~d}$ & $10.55 \mathrm{c}$ & $12.11 \mathrm{c}$ \\
2017 & $(\mathrm{a})$ & $(\mathrm{a})$ & $(\mathrm{a})$ & $(\mathrm{a})$ \\
\hline Rata-rata & 91.45 & 91.45 & 15.88 & 15.88 \\
CV & 14.87 & 14.87 & 12.26 & 12.26 \\
\hline
\end{tabular}

Ket: Nilai sekolom yang diikuti huruf yang sama dan nilai sebaris pada setiap variabel pengamatan yang diikuti huruf yang sama dinyatakan tidak berbeda nyata berdasarkan uji BNT pada taraf nyata 5\%.

Penurunan hasil biji kedelai ini merupakan akibat dari keterbatasan ketersediaan air. Kedelai yang ditanam pada periode akhir mengalami kekurangan air sejak tanaman masih fase vegetatif. Pada fase generatif tanaman semakin tercekam sehingga tidak dapat memenuhi proses pengisian biji secara maksimal. Akibatnya jumlah biji yang terbentuk sedikit dan bobot biji pertanaman menjadi rendah (Brevedan dan Egli, 2003). Hasil Penelitian sebelumnya menyebutkan Cekaman kekeringan selama fase generatif menurunkan hasil kedelai sebesar 34\%-46\% (Taufiq dan Sundari, 2012).

\section{KESIMPULAN}

Keterlambatan waktu tanam kedelai pada musim kemarau menurunkan pertumbuhan dan hasil kedelai karena tanaman mengalami cekaman kekeringan dan suhu terutama pada periode awal tumbuh. Pada waktu panen tanaman kedelai sudah masuk musim hujan sehingga beresiko mengalami kesulitan saat panen dan prosesing. Di Dusun Sesela, kedelai yang ditanam pada periode awal menghasilkan bobot biji lebih berat yaitu : $23.15 \mathrm{~g}$ per tanaman.

\section{DAFTAR PUSTAKA}

Bahrun, A., R. Hasid, dan D. Erawan. 2012. Pengaruh Pengairan Separuh Daerah Akar terhadap Efisiensi Penggunaan Air dan Produksi Kedelai (Glycine max L.) pada Musim Kemarau. Jurnal Agronomi Indonesia, 40(1): 36-41.

Bastidas, A. M., T. D. Setiyono, A. Dobermann, K. G. Cassman, R. W. Elmore, G. L. Graef, dan J. E. Specht. 2008. Soybean Sowing Date: The 
Vegetative, Reproductive, and Agronomic Impacts. Crops Science 48 (March-April): 727-740.

Brevedan, R. E., dan D. B. Egli. 2003. Short Periods of Water Stress during Seed Filling, Leaf Senescence, and Yield of Soybean. Crop Science 43(6): 20832088.

Egli, D. B. dan I. F. Wardlaw. 1980. Temperature Response of Seed Growth Characteristics of Soybeans. Agronomy Journal 72(3): 560-564.

Hapsoh, S. Yahya, T.Oelim, dan D. Sopandie. 2004. Respon Beberapa Genotipe Kedelaiterhadap Tingkat Cekaman kekeringan Tanah Ultisol. Jurnal Agronomi Indonesia 32(3): 1-8.

Hu, M., dan P. Wiatrak. 2012. Effect of planting date on soybean growth, yield, and grain quality: Review. Agronomy Journal 104(3): 785-790.

Nugraha, Y. S., T. Sumarni, dan R. Sulistyono.
2014. Pengaruh interval waktu dan tingkat pemberian air terhadap pertumbuhan dan hasil tanaman kedelai (Glycine max (L) Merril.). Jurnal Produksi Tanaman 2(7): 552-559.

Pedersen, P. dan J.G. Lauer. 2004. Response of soybean yield components to management system and planting date. Agronomy Journal 96(5): 1372-1381.

Rahman, M. M., J.G. Hampton, dan M.J. Hill. 2006. Soybean Seed Yield as Affected by Time of Sowing in a Cool Temperate Environment. Journal of New Seeds (4): $1-15$.

Settimi, J. R., dan J.E. Board. 1988. Photoperiod and Planting Date Effects on the Spatial Distribution of Branch Development in Soybean. Crop Science 28: 259-263.

Sundari, T., dan A. Taufiq. 2012. Respons Tanaman Kedelai Terhadap Lingkungan Tumbuh. Buletin Palawija 26(23): 13-26. 